\title{
EFEK MEROKOK BERAT TERHADAP JUMLAH LEUKOSIT DAN JENIS LEUKOSIT PADA PRIA USIA PRODUKTIF DI KELURAHAN TANJUNG PINANG KOTA PALANGKA RAYA
}

\author{
Effect of Heavy Smoking on White Blood Cell Count and Differential Counting of Leukocytes \\ In Productive Men in Kelurahan Tanjung Pinang, Palangka Raya \\ $1 *$ Rinny Ardina, ${ }^{2}$ Nada Soraya \\ ${ }^{1}$ Universitas Muhammadiyah Palangkaraya, Jl. RTA. Milono Km. 1,5, Palangka Raya, Indonesia \\ ${ }^{2}$ Universitas Muhammadiyah Palangkaraya, Jl. RTA. Milono Km. 1,5, Palangka Raya, Indonesia \\ *e-mail : rinyardina@gmail.com
}

\begin{abstract}
ABSTRAK
Prevalensi perokok laki-laki usia produktif di Kalimantan Tengah tahun 2013 mencapai 64,9\% dengan rerata jumlah batang rokok yang dihisap sekitar 12,3 batang per hari. Asap rokok mengandung $10^{15}$ radikal bebas yang merupakan sumber utama stres oksidatif sel. Stres oksidatif dapat memicu aktivasi gen inflamasi dengan cara meningkatkan pelepasan sitokin inflamasi melalui peningkatan jumlah leukosit dan aktivasi berbagai jenis leukosit. Inflamasi terus-menerus dapat menimbulkan flak penyebab aterosklerosis dan jantung koroner. Tujuan penelitian ini yaitu untuk mengetahui efek merokok berat terhadap jumlah leukosit dan jenis leukosit pada pria usia produktif di Kelurahan Tanjung Pinang Kota Palangka Raya. Metode desktiptif observasional dengan rancangan cross sectional digunakan dalam penelitian. Sampel sebanyak 28 orang diperoleh dengan teknik purposive sampling dengan kriteria: responden berjenis kelamin laki-laki, perokok aktif, merokok lebih dari 10 tahun, bekerja sebagai petani, penambak ikan, atau buruh, dan bersedia menjadi responden. Pemeriksaan jumlah leukosit dan jenis leukosit menggunakan metode otomatis dengan alat Hematology Analyzer. Hasil penelitian menunjukkan sebesar 3,6\% perokok aktif memiliki jumlah leukosit tinggi dan 3,6\% memiliki jumlah leukosit rendah. Hasil jenis leukosit menunjukkan eosinofil tinggi pada 2 orang $(7,10 \%)$, eosinofil rendah pada 5 orang $(17,9 \%)$, neutrofil rendah pada 1 orang $(3,6 \%)$, limfosit tinggi pada 2 orang $(7,20 \%)$, limfosit rendah pada 10 orang $(35,7 \%)$, dan monosit tinggi pada 15 orang $(53,6 \%)$. Kondisi seperti ini apabila terus-menerus dibiarkan dapat meningkatkan risiko terjadinya aterosklerosis dan penyakit jantung koroner. Oleh sebab itu, perlu tindakan preventif dan edukatif dari tenaga medis kepada perokok aktif maupun keluarga perokok aktif agar bersama-sama mencegah bahaya asap rokok terhadap kesehatan.
\end{abstract}

Kata kunci : perokok aktif, merokok, usia produktif, jumlah leukosit, jenis leukosit

\begin{abstract}
Prevalence of productive men smokers in Kalimantan Tengah in 2013 has been reached 64.9\% with mean of smoking about 12.3 cigarettes a day. Cigarette smoke contains $10^{15}$ of oxidative free radicals which can cause an oxidative stress. It will trigger of activation of inflammatory genes and increase of cytokines release by increasing of leukocytes and activate some of differential leukocyte. Continual inflammation can cause atherosclerosis and coronary heart disease.This study aimed to determine the effects of heavy smoking on white blood cell count and differential leukocyte count in productive men in Kelurahan Tanjung Pinang, Palangka Raya. This study used a descriptive observational method with cross sectional design. Sample obtained by 28 people with purposive sampling technique with criteria: men, active smoker, smoking more than 10 years, working as a farmer, fish farmer, or laborer, and willing to become a respondent. White blood cell count and differential leukocyte count was analyzed by automatic method using Hematology Analyzer. The results showed that 3.6\% of active smokers had high white blood cell count and others had low white blood cell count (3.6\%). Whereas, differential leukocyte count showed that 2 persons had high of eosinophils (7.10\%), 5 people had low of eosinophils (17.9\%), one person had low of neutrophils (3.6\%), 2 persons had high of lymphocytes (7.20\%), 10 people had low of lymphocytes (35.7\%), and 15 people had high of monocytes (53.6\%). To reduce the risks, preventive and educative actions from medical personnel are needed for active smokers and their families.
\end{abstract}

Keyword: active smokers, smoking, productive of age, white blood cell count, differential of leukocyte 


\section{PENDAHULUAN}

Proporsi perokok di Kalimantan Tengah termasuk yang cukup tinggi yaitu $22,5 \%$ dan dari data Riset Kesehatan Dasar tahun 2013, prevalensi perokok laki-laki usia produktif di Kalimantan Tengah sebesar 64,9\% dengan rerata jumlah batang rokok yang dihisap adalah sekitar 12,3 batang per hari. Berdasarkan kelompok usia, usia produktif menurut Kemenkes RI tahun 2015 antara 15-64 tahun dan diketahui proporsi terbanyak perokok aktif setiap hari yaitu pada umur 30-34 tahun $(33,4 \%)$ dan pada umur 35-39 tahun (32,2\%) (WHO, 2011; Kemenkes RI, 2016; Kemenkes RI, 2013). Angka ini termasuk cukup tinggi dan sangat dimungkinkan jumlah perokok aktif dari tahun ke tahun akan meningkat terutama di kalangan anak muda.

Asap rokok terdiri dari asap utama (main stream) yang mengandung 25\% kadar bahan berbahaya dan asap sampingan (side stream) yang mengandung 75\% kadar bahan berbahaya (Nurjanah, et al., 2014). Asap rokok mengandung lebih dari 4000 bahan kimia berbahaya, diantaranya nikotin, tar, timbal, karbonmonoksida (CO), polynuclear aromatic hydrocarbons, tobbaco-specific $\mathrm{N}$ nitrosamines and aromatic amines, dan berbagai radikal bebas lainnya yang bersifat karsinogenik (Lymperaki, et al, 2015). Setiap hembusan asap rokok mengandung $10^{15}$ radikal bebas oksidatif yang merupakan sumber utama penyebab stres oksidatif yang berpotensi sebagai mediator disfungsi endotelial, peningkatan trombogenesitas darah, dan respon inflamasi (Vardavas \& Demosthenes, 2009 ; Lavi, et al, 2007).

Ketika asap rokok masuk ke dalam tubuh, akan terjadi respon inflamasi yang ditunjukkan dengan naiknya produksi mediator pro inflamasi yang nantinya akan menaikkan jumlah total leukosit dalam darah. Seseorang yang merokok dalam jangka waktu yang lama secara terus menerus diketahui memiliki jumlah leukosit 20-25\% lebih tinggi dibandingkan orang yang tidak merokok. Diketahui masuknya nikotin ke dalam tubuh yang menyebabkan terjadinya leukositosis akibat bersirkulasinya catecholamine karena kenaikan hormon seperti epinephrine dan kortisol oleh nikotin (Permatasari, 2015).

Peningkatan jumlah leukosit (leukositosis) dan jenis leukosit disebabkan oleh asap rokok yang masuk ke dalam tubuh. Jenis leukosit yang mengalami peningkatan terutama adalah sel polymorphonuclear neutrophil (PMN) (Permatasari, 2015). Penelitian Martantya, et al (2014) menemukan bahwa pada perokok aktif, rata-rata persentase jenis leukosit berada dalam batas normal kecuali neutrofil segmen yang mengalami peningkatan dan limfosit yang menurun. Hasil penelitian Hou, et al (2013) menunjukkan hubungan yang positif antara merokok dengan peningkatan jumlah leukosit, limfosit, neutrofil, monosit, eosinofil, dan basofil. Kandungan radikal bebas dari asap rokok dapat menyebabkan stres oksidatif pada sel. Sehingga terjadilah aktivasi leukosit, diantaranya neutrofil, monosit, dan limfosit sebagai penanda inflamasi (Rajat, 2004). Peningkatan pada jenis-jenis sel ini terutama menyebabkan inflamasi di paru-paru akibat pembentukan sitokin dan interleukin sebagai penanda inflamasi.

Inflamasi merupakan faktor penting untuk mengawali dan mengembangkan risiko aterosklerosis. Keberadaan radikal bebas dari asap rokok memicu aktivasi gen inflamasi. Gen ini selanjutnya memberikan sinyal kepada sel endotelial, sel leukosit polimorfonuklear, mononuklear, dan trombosit untuk meningkatkan pelepasan sitokin inflamasi. Asap rokok yang mengandung kadar radikal bebas yang tinggi dapat menurunkan kemampuan biologis NO (nitric oxide) pada sel dan menyebabkan peningkatan stres oksidatif pada sel. Stres oksidatif yang meningkat pada sel mengakibatkan pembentukan trombosit yang banyak (trombogenesis) diikuti pembentukan fibrin dan trombin berlebihan, sehingga terbentuk trombus di jaringan endotelial dan lama kelamaan akan menjadi flak penyebab aterosklerosis (Barua \& Ambrose, 2013 ; Morris, et al, 2015).

Adapun lokasi yang dipilih untuk dapat memberikan gambaran efek merokok berat terhadap jumlah leukosit dan jenis leukosit pada perokok aktif ialah di Kelurahan Tanjung Pinang, tepatnya di perumahan penduduk di Jalan Bengaris. Lokasi ini diketahui penduduknya cukup banyak berprofesi sebagai petani, buruh dan penambak ikan yang telah dikategorikan oleh Kementerian Kesehatan RI sebagai perokok aktif terbesar berdasarkan jenis pekerjaan. Rata-rata dari perokok aktif ini dapat 
menghabiskan 2 (dua) bungkus batang rokok per hari.

\section{METODE PENELITIAN}

Analisis observasional deskriptif dengan rancangan cross sectional digunakan dalam penelitian ini untuk menggambarkan efek merokok berat terhadap jumlah leukosit dan jenis leukosit pada perokok aktif yang tinggal di Jl. Bengaris RT 001/RW 003 Kelurahan Tanjung Pinang Kota Palangka Raya.

Tahapan penelitian yang dilakukan meliputi: pengumpulan data, klasifikasi, dan pengolahan/analisis data. Sampel yang diperoleh sebanyak 28 orang yang ditentukan dengan rumus Lemeshow (2010) sebagai berikut:

$\mathrm{n}=\frac{Z_{1}-a / 2 \cdot p(1-p)}{d^{2}}$

Keterangan :

$\begin{array}{ll}\mathrm{n} & \text { : Jumlah sampel } \\ \mathrm{p} & \text { : perkiraan proporsi }(0,5) \\ \mathrm{d} & \text { : presisi absolut }(10 \%) \\ \mathrm{Z} 1-\mathrm{a} / 2 & \text { : statistik } \mathrm{Z}(\mathrm{Z}=1,96 \text { untuk } \mathrm{a}=0,05)\end{array}$

Sampel diambil dengan teknik Purposive Sampling dengan kriteria: responden yaitu berjenis kelamin laki-laki, perokok aktif kategori sedang (1020 batang perhari) hingga berat (> 20 batang perhari), merokok lebih dari 10 tahun, bekerja sebagai petani, nelayan, atau buruh, dan bersedia menjadi responden.

Pengambilan sampel dilakukan dengan melakukan observasi terlebih dahulu diikuti pembagian lembar informasi penelitian kepada responden. Lembar informasi penelitian dikumpulkan lalu dipilih responden yang memenuhi kriteria penelitian. Responden yang terpilih diberikan lembar persetujuan (inform consent) dan dilakukan

wawancara. Wawancara bertujuan untuk mengumpulkan informasi terkait aktivitas merokok dan hal lainnya yang dapat mengganggu hasil pemeriksaan di luar aktivitas merokok.

Selanjutnya dilakukan pengambilan sampel darah vena pada responden berdasarkan prosedur baku dari Departemen Kesehatan RI (2008) dengan alat dan bahan antara lain spuit $3 \mathrm{cc}$, tabung vakum ungu ( $\left.\mathrm{K}_{3} \mathrm{EDTA}\right)$, tourniquet, kapas alkohol $70 \%$, dan plester. Pemeriksaan hitung jumlah leukosit dan jenis leukosit menggunakan metode otomatis dengan alat dan bahan antara lain Hematology Analyzer, sampel darah EDTA, dan reagen cell pack, stromatolyser, dan cell clean. Data yang diperoleh dari hasil wawancara, pemeriksaan jumlah leukosit, dan jenis leukosit selanjutnya dimuat dalam bentuk tabel yang telah diklasifikasikan berdasarkan karakteristik responden. Data dalam tabel kemudian dianalisis dan dideskripsikan dalam bentuk persentase (\%) (Sudijono, 2010).

\section{HASIL DAN PEMBAHASAN}

Pemeriksaan sampel darah dari perokok aktif yang tinggal di Jl. Bengaris RT 001/RW 003 Kelurahan Tanjung Pinang Kota Palangka Raya dianalisis di Laboratorium Instrumentasi Fakultas Ilmu Kesehatan Universitas Muhammadiyah Palangkaraya. Berikut adalah data hasil pemeriksaan yang dimuat sebagai tabel karakteristik responden dan persentase jumlah leukosit dan jenis leukosit pada perokok aktif di Jl. Bengaris RT. 001/RW. 003 Kelurahan Tanjung Pinang Kota Palangka Raya.

TABEL 1. Karakteristik Responden

\begin{tabular}{|c|c|c|c|}
\hline \multirow{2}{*}{ NO } & \multirow{2}{*}{$\begin{array}{l}\text { KARAKTERISTIK } \\
\text { RESPONDEN }\end{array}$} & \multicolumn{2}{|c|}{ Frekuensi } \\
\hline & & Jumlah & $\begin{array}{c}\text { Persentase } \\
(\%)\end{array}$ \\
\hline \multirow[t]{5}{*}{1.} & Usia (tahun) & & \\
\hline & $20-30$ & 8 & 28,6 \\
\hline & $31-40$ & 11 & 39,3 \\
\hline & $41-50$ & 4 & 14,3 \\
\hline & $51-60$ & 5 & 17,8 \\
\hline \multirow[t]{4}{*}{2.} & Lama Merokok (tahun) & & \\
\hline & $1-10$ tahun & 9 & 32,1 \\
\hline & $11-20$ tahun & 9 & 32,1 \\
\hline & $>20$ tahun & 10 & 35,8 \\
\hline \multirow[t]{4}{*}{3.} & $\begin{array}{l}\text { Jumlah Rokok yang } \\
\text { Dihisap Per Hari }\end{array}$ & & \\
\hline & $1-10$ batang/hari & 8 & 28,6 \\
\hline & 11-20 batang/hari & 10 & 35,7 \\
\hline & $>20$ batang/hari & 10 & 35,7 \\
\hline
\end{tabular}


TABEL 2. Gambaran Jumlah dan Jenis Leukosit Pada Perokok Aktif di Kelurahan Tanjung Pinang

\begin{tabular}{|c|c|c|c|c|c|c|c|}
\hline \multirow{3}{*}{ No. } & \multirow{3}{*}{ Variabel } & \multicolumn{6}{|c|}{ Frekuensi $(\%)$} \\
\hline & & \multicolumn{2}{|c|}{ Rendah } & \multicolumn{2}{|c|}{ Normal } & \multicolumn{2}{|c|}{ Tinggi } \\
\hline & & Frekuensi & Persentase (\%) & Frekuensi & Persentase (\%) & Frekuensi & Persentase (\%) \\
\hline 1. & $\begin{array}{l}\text { Jumlah } \\
\text { Leukosit }\end{array}$ & 1 & 3,6 & 26 & 92,8 & 1 & 3,6 \\
\hline \multirow[t]{5}{*}{2.} & $\begin{array}{l}\text { Jenis } \\
\text { Leukosit } \\
\text { Eosinofil }\end{array}$ & 5 & 17,9 & 21 & 75,0 & 2 & 7,10 \\
\hline & Basofil & 0 & 0 & 28 & 100 & 0 & 0 \\
\hline & Neutrofil & 1 & 3,6 & 27 & 96,4 & 0 & 0 \\
\hline & Limfosit & 10 & 35,7 & 16 & 57,1 & 2 & 7,20 \\
\hline & Monosit & 0 & 0 & 13 & 46,4 & 15 & 53,6 \\
\hline
\end{tabular}

Mayoritas (39,3\%) responden berusia 20-30 tahun dan 28,6\% lainnya berusia 31-40 tahun. Perokok aktif paling banyak merokok $\geq 20$ tahun (35,8\%) dengan jumlah konsumsi rokok/hari 11-20 batang rokok/hari sebesar 35,7\%, dan $\geq 20$ batang rokok/hari sebanyak 35,7\%. Penelitian Taher Sih, et al (2017) mendapati adanya peningkatan pada jumlah leukosit, limfosit dan neutrofil pada perokok aktif yang rata-rata merokok lebih dari 8 tahun dengan rentang usia 20-50 tahun. Hou, et al (2013) dalam studi prospektifnya menemukan peningkatan jumlah leukosit dan jenis leukosit pada perokok yang merokok selama 20 tahun sejak mereka berusia 18-30 tahun hingga 20 tahun kemudian.

Pada tabel 2 terdapat 1 orang $(3,6 \%)$ dengan jumlah leukosit tinggi, 1 orang $(3,6 \%)$ dengan jumlah leukosit rendah dan 26 orang $(92,8 \%)$ dengan jumlah leukosit normal. Leukositosis ditemukan pada 1 orang responden $(3,6 \%)$ berusia diatas 32 tahun. Hasil ini sejalan dengan penelitian Al-temimi (2017) yang menemukan adanya peningkatan jumlah leukosit pada perokok aktif dengan rentang usia 3039 tahun dan semakin meningkat pada usia 40-49 tahun. Penelitian Ergun, et al (2007) yang melakukan studi kasus pada perokok aktif berusia 41 tahun dan juga ditemukan jumlah leukosit meningkat. Berdasarkan lama merokok, diketahui 2 orang dengan leukositosis merokok $>20$ tahun. Hasil ini juga ditemukan pada penelitian Takahashi, et al (2012) dimana perokok aktif $>20$ tahun menunjukan peningkatan leukosit secara signifikan.

Adapun jumlah rokok yang dikonsumsi oleh perokok aktif yang menyebabkan leukositosis dalam penelitian ini adalah konsumsi rokok >20 batang/hari. Hasil ini serupa dengan penelitian Terakura, et al (2010) yang menemukan jumlah rokok yang dihisap per hari >20 batang dapat meningkatkan jumlah leukosit secara signifikan. Namun dalam penelitian ini ada pula beberapa perokok yang mengkonsumsi >20 batang/hari, ditemukan jumlah leukosit normal seperti halnya dalam penelitian Takahashi et al (2012) yang menemukan jumlah leukosist normal pada perokok yang merokok 40 batang/hari.

Leukositosis pada perokok dapat diakibatkan oleh peningkatan radikal bebas yang memicu terjadinya proses inflamasi sistemik dalam tubuh baik akut maupun kronik. Respon inflamasi sistemik ditandai dengan stimulasi dari sistem hemopoietik (pembentukan darah), terutama oleh sumsum tulang yang kemudian akan melepaskan leukosit ke dalam sirkulasi. Beberapa studi telah membuktikan bahwa leukositosis terjadi sebagai akibat paparan asap rokok kronik. Leukositosis terutama terjadi pada sel polymorphonuclear neutrophil (PMN) di dalam sirkulasi yang berguna untuk rekrutmen sel PMN ke jaringan yang mengalami inflamasi. Leukositosis yang terjadi pada perokok menjadi faktor risiko berbagai penyakit sistem imun, salah satunya adalah faktor risiko penyakit jantung koroner dan penurunan fungsi paru-paru (Yanbaeva, et al, 2007).

Leukositosis akibat komponen radikal bebas dari asap rokok merupakan penanda berbagai penyakit, terutama penyakit jantung akut. Diketahui bahwa leukositosis pada pasien tanpa komplikasi jantung memiliki peningkatan risiko penyakit jantung 
dikemudian hari. Sehingga, leukositosis tidak hanya sebagai penanda peningkatan risiko penyakit jantung tetapi juga memainkan peranan penting dalam patofisiologi dari aterosklerosis (Lavi, et al, 2007). Pada penelitian ini diperoleh jumlah leukosit rendah (leukopeni) pada 1 orang responden $(3,6 \%)$.

Penurunan jumlah leukosit dapat dipengaruhi pula oleh beberapa faktor diantaranya infeksi berat, penyakit aotuimun, kanker, terapi mengunakan radiasi dan mengonsumsi obat-obat seperti antibiotik, anti kejang dan anti hipertensi. Pada 1 orang responden yang menunjukan leukopeni diketahui rutin mengkonsumsi obat antihipertensi yang dapat menyebabkan rusaknya dinding sel leukosit dan menyebabkan keadaan leukopenia (Sutedjo, 2006).

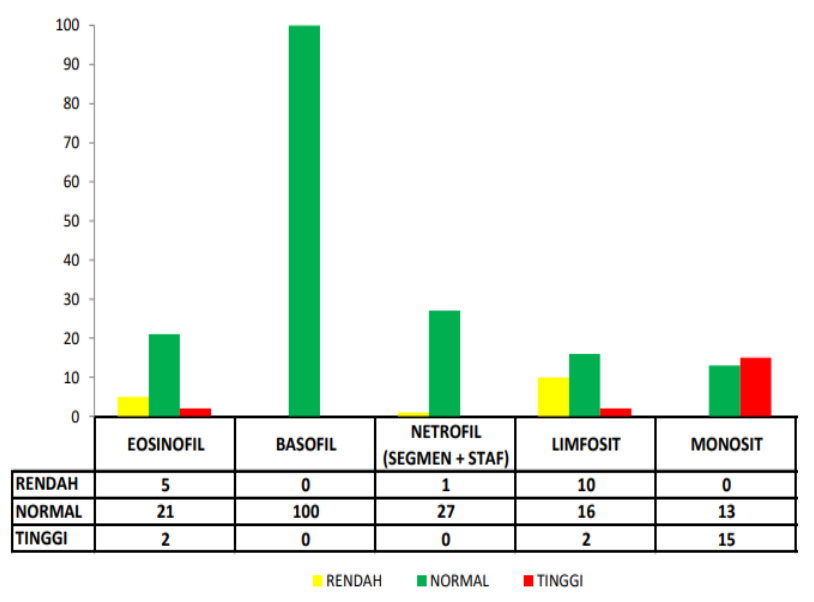

Grafik 1. Hitung Jenis Leukosit

Pada hasil jenis leukosit terdapat 2 orang $(7,10 \%)$ eosinofil tinggi, 5 orang $(17,9 \%)$ eosinofil rendah, dan 21 orang $(75,0 \%)$ eosinofil normal, tidak ditemukan basofil (100\% normal), tidak ditemukan neutrofil tinggi $(0 \%), 1$ orang $(3,6 \%)$ neutrofil rendah, dan 27 orang $(96,4 \%)$ neutrofil normal. Selanjutnya 15 orang $(53,6 \%)$ dengan monosit tinggi, tidak ditemukan monosit rendah $(0 \%), 13$ orang $(46,4)$ monosit normal, 2 orang $(7,20 \%)$ limfosit tinggi, 10 orang $(35,7 \%)$ limfosit rendah dan 16 orang $(57,1 \%)$ limfosit normal. Hasil ini sejalan dengan penelitian Lavi, et al (2007) yang menemukan adanya limfositosis (limfosit tinggi), monositosis (monosit tinggi), dan eosinofilia (eosinofil tinggi) pada perokok aktif yang terpapar asap rokok dalam jangka waktu yang lama minimal setelah satu jam paparan asap rokok. Neutrofil diketahui terlibat dalam aterogenesis dikarenakan mampu merusak sel endotel dan berinteraksi dengan protein kemoatraktan monosit, sehingga terjadi pelepasan monosit berlebih ke sirkulasi. Limfosit muncul sebagai penyebab aterosklerosis karena fungsinya dalam mensekresi sitokin inflamasi dan produksi imunoglobulin. Begitu pula dengan eosinofil yang teraktivasi sehingga mengeluarkan sejumlah protein yang bersifat aterogenesis (Hou, et al 2013). Peningkatan pada beberapa jenis leukosit ini juga ditemukan pada penelitan Kerbala (2017), yang melakukan studi kasus pada perokok aktif dimana didapati adanya peningkatan limfosit dan eosinofil secara signifikan pada perokok aktif.

Hasil penelitian Jain, et al (2014), menemukan adanya peningkatan jumlah monosit dan limfosit pada perokok. Peningkatan jumlah limfosit dan monosit pada perokok dapat disebabkan karena sisa inflamasi kronik pada saluran pernapasan, sedangkan peningkatan eosinofil pada perokok dapat diakibatkan oleh alergi di dalam saluran pernapasan. Dalam penelitian ini juga didapatkan 2 orang $(7,0 \%)$ dengan neutrofil rendah. Hasil ini serupa dengan penelitian Segel (2013) yang mendapatkan hasil penurunan neutrofil pada perokok aktif. Penurunan jumlah eosinofil pada 5 orang $(17,9 \%)$ perokok aktif dalam penelitian ini juga ditemukan pada penelitian Berania, et al (2014) dimana jumlah eosinofil perokok aktif lebih rendah dibandingkan dengan nonperokok. Jumlah eosinofil rendah dapat disebabkan oleh adanya kandungan nikotin pada asap rokok. Dimana menurut Zakariah (2010) penurunan eosinofil secara statsitik bermakna berdasarkan lamanya intervensi nikotin.

\section{KESIMPULAN}

Hasil penelitian ini menunjukkan bahwa pada perokok aktif sebanyak 3,6\% \% jumlah leukosit tinggi dan 3,6\% jumlah leukosit rendah. Selain itu, diperoleh hasil hitung jenis leukosit yang abnormal (rendah atau tinggi) terutama pada sel eosinofil, neutrofil, limfosit dan monosit yang merupakan sel penanda inflamasi. Kondisi seperti ini apabia terusmenerus dibiarkan dapat meningkatkan risiko terjadinya aterosklerosis yang berujung pada penyakit jantung koroner bahkan yang lebih fatal lagi adalah kematian. Oleh sebab itu, perlu tindakan preventif dan edukatif dari tenaga medis baik kepada perokok aktif maupun keluarga disekitar perokok aktif agar 
bersama-sama mencegah bahaya asap rokok terhadap kesehatan.

\section{DAFTAR PUSTAKA}

Al-Temimi, S, Q., 2017. The Effect of Cigarette Smoking on Some Blood Parameters, Blood Pressure and Renal Function Test. Jurnal University of Kerbala. 15(1):1-10.

Badan Penelitian dan Pengembangan Kesehatan. 2013. Riset Kesehatan Dasar 2013. Kementerian Kesehatan RI.

Barua., R. S., \& Ambore, A. 2013. Mechanisms of Coronary Thrombosis in Cigarette Smoke Exposure. Arteriosclerosis,Thrombosis and Vascular Biology Journal Impact. 33:14601467.

Berania, I., Endam, L. M., Filali-Mouhim, A., Boisvert, P., Boulet, L., Bosse, Y., \& Desrosiers, M. 2014. Active Smoking Status in Chronic Rhinosinusitis is Associated With Higher Serum Markers of Inflammation and Lower Serum Eosinophilia. International Forum of Allergy \& Rhinology. 4(5):347-352.

Departemen Kesehatan Republik Indonesia. 2008.

Pedoman Praktik Laboratorium yang Benar. Jakarta : Depkes RI.

Ergun, I. 2007. Acute Renal Infarction in A Heavy Smoker. Journal International Urology and Nephrology. 39:951-954.

Hou, L., Lloyd-Jones, D. M., Ning, H., Huffman, M. D., Fornage, M., He, K., Zhang, X., Jacobs, D. R., Goff, D. C., Sidney, S., Carr, J. J., \& Liu, K. 2013. White Blood Cell Count in Young Adulthood and Coronary Artery Calcification in Early Middle Age: Coronary Artery Risk Development in Young Adults (CARDIA) Study. European Journal of Epidemiology. 28:735-742.

Jain, S.K., Agarwal, S., \& Agarwal, S.K. 2014. Correlation Between The Stature and Cranial Measurements in Population of North India. Journal Acta Medica International. 1(2):99-102.

Kementerian Kesehatan Republik Indonesia. 2016. Profil Kesehatan Indonesia Tahun 2015. Kementerian Kesehatan Republik Indonesia. 1220.
Kerbala. 2017. Determination of Some Hematological Parameters among Healthy Smokers in Khartoum State. Journal Sudan University of Science and Technology. 5(5):5256.

Lavi, S., Abhiram, P., Eric, H. Y., et al. 2007. Smoking is Associated with Epicardial Coronary Endothelial Dysfunction and Elevated White Blood Cell Count in Patients with Chest Pain and Early Coronary Artery Disease. Circulation. 115:2621-2627.

Lemeshow, S., David, W. H., Janelle, K., \& Stephen, K. L. 1997. Besar Sampel Dalam Penelitian Kesehatan. Terjemahan Dibyo Pramono. Yogyakarta, Gadjah Mada University Press.

Lymperaki, E., Makedou, K., Iliadis, S., \& Vagdatli, E., 2015. Effects of Acute Cigarette Smoking on Total Blood Count and Markers of Oxidative Stress in Active and Passive Smokers. Hippokratia. 19(4):293-297.

Martantya, R.S., Nasrul, E., \& Basyar, M. 2014. Gambaran Hitung Jenis Leukosit Pada Pasien Penyakit Paru Obstruktif Kronik yang Dirawat Di RSUP Dr. M. Djamil Padang. Jurnal Kesehatan Andalas. 3(2):217-220.

Morris., P. B., Ference, B. A., Jahangir, E., et al. 2015. Cardiovascular Effects of Exposure to Cigarette Smoke and Electronic Cigarettes. Journal of The American College of Cardiology. 66(12):1378-1391.

Nurjanah, Lily, K., \& Abdun, M. 2014. Jurnal Kesehatan Masyarakat. 10(1):43-52.

Permatasari, N. D., \& Probosari, E. 2015. Pengaruh Pemberian Sari Batang Nanas (Ananas comosus) Terhadap Total Leukosit Tikus Wistar yang Diberi Paparan Asap Rokok. Journal of Nutrition College. 4(2):264-270.

Rajat. 2004. The Pathophysiology of Cigarette Smoking and Cardiovascular Disease. Jurnal of the American Collage of cardiology. 43(10):1732-1734.

Sudijono, A. 2010. Pengantar Statistik Pendidikan. Jakarta, Rajawali Pers.

Sutedjo. 2006. Buku Saku Mengenal Penyakit Melalui Pemeriksaan Laboratorium Edisi Revisi. Yogyakarta, Amara Books.

Taher Sih, B., Alqasim, A. M. Z., \& Ajil, A. H. 2017. The Effect Of Gamma Ray On Total Leukocytes, 


\section{BJMLT}

Lymphocytes and Neutrophils on Blood Samples of Smokers Compared to Non-Smoker Donors. Iraqi Journal of Hematology. 6(1):1-5.

Takahashi, M., Yamahira, A., \& Uchiyama, T. 2012. Idiopatic Macrocytosis in Smokers. Original Article. 27:689-696.

Terakura, M., Kubota, H., Ueno, H., \& Mukaiyama, Y. 2010. Association Between Lifestyle Habits And White Blood Cell Count. Jurnal Japan Society of Ningen Dock. 24:7-11.

Vardavas, C. I., \& Demosthenes, B. P. 2009. The Causal Relationship Between Passive Smoking and Inflammation on the Development of Cardiovascular Disease : A Review of the Evidence. Inflammation and Allergy - Drug Targets. 8(5):328-333.

WHO. 2011. Global Adult Tobacco Survey : Indonesia Report 2011. Indonesia.

Yanbaeva, D.G., Dentener, M.A., Creutzberg, E.C., Wesseling, G., \& Wouters Emiel, F.M. 2007. Systemic effect of smoking. Journal Chest. 131:1557-66.

Zakariah, L. M. S. 2010. Analisis Hematologi Nilai Kecernaan dan Tingkah Laku Monyet Ekor Panjang (Macaca fasciclaris) Jantan Obes yang Diintervensi Nikotin. Tesis. Institut Pertanian Bogor, Bogor. 